\title{
The Dichotomy of Specialization: Is a Literature Teacher Necessarily a Language Teacher?
}

\author{
Mariam Anana \\ http://dx.doi./org/10.4314/ujah.v21i2.6
}

\section{Abstract}

This study investigates the dichotomy of specialization in Literature and English language. In many primary and secondary schools in Nigeria, many teachers who teach Literature are the same teachers who teach English Language. This is responsible for lack of ultimate successes in academic performance, foundational establishment and progressive developments in Literature and English language. Set against the backdrop of the inseparability and non-specialization in individual subjects in question, the study examines the need for a dichotomy of specialization in English Language and Literature with a view to reducing the rate of errors and students' failures in both subjects. Adopting the simple randomisation, the researcher uses selected primary and secondary schools in Lagos State as the case study; the paper raises four questions and these are: Can English Language teachers effectively teach poetic devices? Are segmental phonemes easily taught by Literature teachers? Can English Language teachers proficiently teach oral literature, literary criticism and non-African literature? Can Literature teachers competently teach stress and intonation? This research uses a qualitative approach and adopts The Speech Act Theory as its theoretical framework. Questionnaire of fifteen (15) items was used for data collection and the simple percentage was applied for data analysis. The researcher discovered that: It is not possible for English Language teachers to effectively teach poetic devices. Segmental phonemes 
cannot be easily taught by Literature teachers. Students would lag behind in areas where teachers are not proficient in the subjects they teach. Also, it is not possible for a teacher to place equal emphasis on both English Language and Literature in classrooms. The study therefore recommends the need for a dichotomy of specialization in the two subjects so as to ensure effective teaching and learning of these subjects.

Keywords: Dichotomy, inseparability, literary criticism, academic performance, segmental phonemes

\section{Introduction}

The current falling standard of education in the English language and literature in Nigeria; with its attendant failure in students' performance in and outside the classes, in internal and external (terminal) examinations is not unconnected with the fact that many English language teachers are the same teachers who teach literature. No one can claim to do two things simultaneously and achieve the same result; one of the things must suffer lack of maximal concentration. Musgrove (1974) observes that not only knowledge in science and technology decay rapidly, but that in most subject areas there have been major modifications. One of such modifications is the issue of a teacher taking subjects that he or she is not very competent in.

Teaching, according to Moore (1992 cited in Ayodeji 1998) is the action of someone (a teacher) who tries to assist others to reach their fullest potential in all aspects of their developments. A teacher is expected to teach effectively so as to imbibe these potentials in the recipients (pupils and students). Musgrove, (1974) states that a teacher arises out of what is popularly referred to as 
the "Knowledge explosion". Ayodeji (1998) states that the teachers' power consists chiefly of four components namely:

i. Charisma: the ability of the teacher to attract and influence people with higher personality

ii. Dominance: the ability to obtain control over a situation

iii. Intellectual power: teachers' knowledge and mastery of his/her subject

iv. Resources power: teachers' ability to organize all aspects of works in the classroom

The pupils in Nigeria also expect their teachers to be models of perfection especially in the exhibition of their intellectual power. They expect their teachers to be knowledgeable in the subjects they teach and in their areas of specialization (Mannheim and Steward, 1962 cited in Musgrove). Cohen and Manhen (1977 cited in Musgrove) observe that the central task of the teacher has to do with the transmission of specific knowledge and culture to the younger ones so that what the society holds as valuable can be conserved by each succeeding generation. In the same vein, Peter (1966) in his historical study views the teacher as the transmitter of knowledge and values.

In many primary and secondary schools where teachers teach both English and literature simultaneously, some of these teachers fail in their responsibility to transmit knowledge accordingly to their pupils and students and this trend is quite worrisome.

This research therefore investigates the dichotomy of specialisation between language teacher and the literature teacher with a view to identifying exactly what the English Language and 
Anana: The Dichotomy of Specialization: Is a Literature Teacher Necessarily a Language Teacher?

teachers should teach competently in both primary and secondary schools in Nigeria.

\section{Research Questions}

The research questions for this paper are as follows:

1. What are the topics that the English Language teachers and Literature teachers are expected to teach effectively?

2. Are there impacts of teachers' non-specialisation in English Language and Literature?

3. What is the significance of the dichotomy of specialisation by individual teachers?

\section{English Language}

English language is a West Germanic language of the IndoEuropean language family that is closely related to Frisian, German and Dutch. It originated in England and it is the dominant language in the United States (Poller and Crystal).

The history of the English language dates to 449AD when the Angles, Saxon and Jutes sailed over their homes in Denmark and Germany and invaded the British Isles. They came with their language and today scholars call it the Anglo-Saxon or Old English. The language quickly overtook Celtic, the language of the native Briton and the British Isles, henceforth became English speaking (McCrum, Cran and Macneil, online)

The major change in English came in 597, when St. Augustine and his monks were sent to convert the inhabitants of the future England to Christianity. They brought with them the Greek and Latin handy words to express complicated ideas.

Anglo-Saxon had plenty of simple words, but their vocabulary was very limited when it came to more complex ideas. The terminology of the church filled in this gap, by introducing 
into Old English many new words of Latin origin as well as Greek and some Hebrew.

Next was the Viking raids, beginning in the mid 700s and continued until Alfred the Great defeated the Danes and Norsemen in 878. The Vikings spoke Old Norse. During the successful period of the raids, the English language was almost in danger of being wiped out because of the extensiveness of the Vikings conflicts. Fortunately for English, Alfred won the war and afterwards, in a move towards political solidarity emphasized the necessity of the English language. In order to do this, he had many works of Latin translated into English. So the Vikings raid, instead of wiping out English, had the effect of making it more deeply ingrained, although Norse did have profound effect on English language and many of our modern English words are of Scandinavian origin.

The important event that ultimately changed Old English to modern English came in 1066, with the Norman invasion. This invasion brought French-speakers into power in England, a fact that had enormous consequences for the English language. Since French was the language of the powerful people, all "official business was conducted in French and Latin.

\section{The Concept of Literature}

Unlike other disciplines, the term literature is said to be difficult to define (Osagie, 2004). The meaning seems to undergo changes. However, many scholars have attempted the definition of literature. Literature refers to written words; but it is not all written forms that are regarded as literary works. Literature is "any given writing belonging to a period, a region or language group. It has subdivisions with no distinct borders (Osajie). Anana (2013) defines literature as any oral or written imaginative and aesthetic works of arts. She further states that literature deals with 
remarkable works of great personalities who have contributed immensely to the growth and development of cultures and civilizations. Anana also states that every society has both oral and written literature. Oral literature, she maintains is the traditional form while the written form is the modern literature that everyone is familiar with.

Commenting on oral literature, Finnegan (1984) states that the unwritten form is far less widely known and appreciated. She also notes that it is harder to record and present it. She further states that oral literature is dependent on the performers who formulate it in words on a specific occasion.

\section{Types of Literature}

Literature is divided into four categories, technically known as genres and these are prose fiction (or narrative fiction), drama, poetry and non-fiction prose. The first three are imaginative while the last genre deals with realities of life. The prose fiction includes the parables, romances, novels, novella (novelette), short stories and myths.

The Prose: This is a free flowing long narrative that may take the form of fiction and non-fiction.

Fiction: The word fiction initially means anything crafted or shaped, but today, it is an expansive prose story based on the imagination of the writer or author. The essence of prose fiction is narrative that relates or recounts a sequence of events or actions. Fictions normally focus on one or few main characters. Fictional works can introduce true historical events but they are not real histories and the real purposes for fictions are to stimulate interest, instruct and direct but not to create real historical record. 
Drama: is designed for stage or film presentation by actors for the benefits of the audience. Drama is meant for the development of character and situation through speech and action. Drama may have a single character, a small number of characters or even many characters. The major subdivisions of drama are tragedy, comedy and tragi-comedy.

Poetry: The language used in poetry is always concise or brief. Poetry offers a high point of emotion. It power lies not only in words and thoughts but in its rhyme and a variety of rhythms to intensify its emotional impact. Poems vary in length and lines, and distil the greatest meaning and imaginative power of words through rhetorical devices such as imagery and metaphor. Poetry normally requires formal and metrical restrictions. Some types of poems are ballads, blank verse quatrain, couplets, elegies, epigrams, hymns, limericks, odes, songs or lyrics, tercets or triplets, villanelles, haiku, elegy and epic.

Non-fiction Prose: This consists of journals, dairies, feature articles, essays, editorials, news reports, historical and biographical works, histories and the like. Non- fictions describe and interpret facts and present judgement and views and the essence of nonfiction prose is to present truths and resolutions about factual world.

\section{Differences between English and Literature}

i. English language has distinct borders, literature does not have.

ii. Literature is mainly narrative; English language is narrative, descriptive, mathematical and argumentative in nature.

iii. Literature involves varied volume of writing and reading; English language does not. 
iv. English language is conventional and arbitrary, literature is not.

v. Language is rigid, (segmental and suprasegemental phonemes remain unchanged); literature is flexible ( writers, dramatists and especially poets can twist literary language to suit their write-ups)

vi. Language is rule governed; literature is not.

vii. Literature always uses language as one of its tools for communication, English Language may not use literature for communication.

viii. In many contexts, English language is simple because of its denotative interpretations while Literature is complex as a result of its connotative meanings.

ix. Language has two major forms(oral and written); literature has three genres (prose, drama, poetry)

$\mathrm{x}$. Literature is the mirror of the society; language is not.

\section{Factors Responsible for the Merger of Literature and English Language Teaching}

There are certain factors that are responsible for the merger of literature and English language teaching. One of these factors is the paucity of specialised teachers. Many people are not interested in English and literature possibly because of lack of respect for the English Language and Literature teachers. This disregard might have been informed by the view of people toward these teachers (that they are not rich). The consequence of this is that there is dearth of specialized teachers in English language and literature.

Lack of finance by private and public school administrators is another possible reason why English and literature is taught by one teacher. There is inflation in the country. The available fund is not sufficient for them to run their schools and as such they feel 
they can manage the fund by employing teachers who they thought can teach the two subjects in question.

The economy of the nation is a potential thread to teachers' specialization in either English or literature. The questions that everyone should address are: How many English and literature trainees or undergraduates do we have in Nigeria? How many do we graduate every year? How many are willing to teach after graduation? How much do the government and private schools pay English or a literature teacher? Since the answers to the above questions are all negative and discouraging, today's graduates prefer going to work in oil companies rather than teaching.

Lack of cooperation by Parents Teacher's Association (PTA) also contributes to lack of specialized teachers in these subjects. The non-challant attitude and refusal to contribute meaningfully for the sustainability of English and literature experts is worrisome and contributory to lack of specialized experts. This group somehow believe that Corp Members are very cheap to pay; they even detain them after the expiration of their service year so as to pay them peanut instead of employing specialized teachers to teach.

\section{Problems Created by the Merger}

The merger has created a number of problems; some of which cannot be remedied. It should be noted that the type of students produced are the reflection of the teachers' input; and since the teachers are not specialized, they cannot get students that are good in these subjects. Even if these students manage to pass both internal and external examinations, they cannot be said to be proficient in English and literature.

There is a possibility of a teacher to always digress to the area he or she specializes thereby leaving the other areas to suffer. 
In other words, the teacher is likely going to place emphasis on one subject over the other. The students, who are the immediate beneficiary, will be the ones who will feel the impacts of the teachers' action. The teacher himself or herself will not be fulfilled because he/she knows that he/she has not done justice to the situation in question.

There is also a tendency for the teacher to select only those areas that he/she knows he/she can handle and leave the rest of the syllabuses uncovered. This action will result in poor performance of students because the areas he/she did not cover may be the same that the examination questions may be set. Again, the teacher will not have any time of relaxation because managing the two subjects is quite hectic.

Selective teaching, based on what individual teachers prefer rather than concentrating on the syllabuses, will have a lasting negative impression on students' career choices and the nation's educational system as a whole. Where young men and women are specializing in what they do not know, it sends a very bad signal to the nation's unity.

\section{The Speech Act Theory}

The first presentation of what has come to be acknowledged as The Speech Act Theory is a series of lectures delivered by Austin in How to Do Things with Words in 1962 (Austin, 1962). Austin first identifies two major types of speech acts: the performatives and the constatives. He explains that some utterances seem to lack the truth-value and that such statements can neither "describe nor report" anything nor the uttering of such be described as saying something. These utterances are performatives. He distinguishes performatives from constatives (declarative statements, that their truth or falsity can be judged). Performatives are also said to be 
felicitous or non-felicitous (i.e. happy or unhappy).

Having realised the confusion created by demarcating performatives from constatives, Austin shifts his arguments to utterances. According to him, all utterances perform speech acts and these comprise a locutionary act, an illocutionary act and a perlocutionary act. A locutionary act is the production of the sounds and words that are meaningful; an illocutionary act is the conventional communicative force while a perlocutionary act is the actual effect achieved by saying something.

The aspects of Austin's Speech acts that are relevant to this paper are his utterances; the locutionary, illocutionary and the perlocutionary acts. The teachers of English Language and Literature are actually uttering words (i.e. teaching) and this accounts for the locutionary act. The illocutionary act is expressed where both teachers are actually doing things with words (i.e. impacting knowledge). The perlocutionary act is the impact of what they actually do with their words. The paper maintains that there should be a dichotomy of specialisation in English Language and Literature by the teachers of these subjects. This is to ensure that there are proficiency, competence and effective teaching and learning of English Language and Literature in primary and secondary schools in Nigeria.

\section{Methodology}

The study adopts an expost factor design because the variables were not manipulated at all.

\section{Data Presentation, Analysis and Findings}

Data collected through questionnaire were analyzed using simple percentage and frequency count. Questionnaire that contains 
Anana: The Dichotomy of Specialization: Is a Literature Teacher Necessarily a Language Teacher?

fifteen items were distributed to 200 respondents (teachers from selected secondary schools in Lagos) as shown below:

\section{Table 1: Frequency Distribution}

\begin{tabular}{|c|c|c|c|c|c|}
\hline & ITEMS & A & SA & $\mathrm{D}$ & SD \\
\hline 1 & $\begin{array}{l}\text { Every English language teacher is } \\
\text { capable of teaching literature } \\
\text { successfully }\end{array}$ & 10 & 20 & 75 & 95 \\
\hline 2 & $\begin{array}{l}\text { Literature should be taught by } \\
\text { literature experts (qualified teachers) } \\
\text { and English by English teachers. }\end{array}$ & 70 & 105 & 15 & 10 \\
\hline 3 & $\begin{array}{l}\text { It is possible for a teacher to place } \\
\text { equal emphasis on both language and } \\
\text { literature in classrooms }\end{array}$ & 21 & 12 & 80 & 87 \\
\hline 4 & $\begin{array}{l}\text { Student's career choices are not } \\
\text { affected if a teacher teaches both } \\
\text { literature and English language }\end{array}$ & 30 & 20 & 79 & 71 \\
\hline 5 & $\begin{array}{l}\text { There would be dearth of } \\
\text { specialization if the subjects are } \\
\text { handled by one teacher }\end{array}$ & 80 & 85 & 15 & 20 \\
\hline 6 & $\begin{array}{l}\text { Teachers' specialization in English } \\
\text { and Literature does not affect } \\
\text { student's performance. }\end{array}$ & 25 & 18 & 85 & 72 \\
\hline 7 & $\begin{array}{l}\text { Students would lag behind in areas } \\
\text { where teachers are not proficient in } \\
\text { teaching. }\end{array}$ & 65 & 72 & 40 & 23 \\
\hline 8 & $\begin{array}{l}\text { Stress patterns cannot be effectively } \\
\text { taught by many literature teachers }\end{array}$ & 95 & 70 & 18 & 17 \\
\hline 9 & $\begin{array}{l}\text { Phonological analysis suffers when } \\
\text { Literature teachers handle English } \\
\text { language }\end{array}$ & 89 & 57 & 30 & 24 \\
\hline 10 & criticisms & 70 & 60 & 40 & 30 \\
\hline
\end{tabular}




\begin{tabular}{|l|l|l|l|l|l|}
\hline & $\begin{array}{l}\text { effectively taught by English } \\
\text { language teacher }\end{array}$ & & & & \\
\hline 11 & $\begin{array}{l}\text { Oral Literature cannot be effectively } \\
\text { handled by English teachers }\end{array}$ & 40 & 45 & 70 & 45 \\
\hline 12 & $\begin{array}{l}\text { Non-African Literature cannot be } \\
\text { competently taught by English } \\
\text { teachers }\end{array}$ & 53 & 54 & 62 & 31 \\
\hline 13 & $\begin{array}{l}\text { Literature teachers can teach oral } \\
\text { English effectively. }\end{array}$ & 50 & 49 & 63 & 38 \\
\hline 14 & $\begin{array}{l}\text { Students taught by English language } \\
\text { experts may not be proficient in } \\
\text { poetic devices. }\end{array}$ & 70 & 60 & 40 & 30 \\
\hline 15 & $\begin{array}{l}\text { Literature teachers may not be able to } \\
\text { teach Semantics effectively }\end{array}$ & 65 & 64 & 40 & 31 \\
\hline & TOTAL & 833 & 791 & 752 & 624 \\
\hline
\end{tabular}

Table 2

\begin{tabular}{|l|l|l|l|l|l|}
\hline & QUESTIONNAIRE ITEM & A & SA & D & SD \\
\hline 1 & $\begin{array}{l}\text { Every English language teacher is } \\
\text { capable of teaching literature } \\
\text { successfully }\end{array}$ & $1.20 \%$ & $2.52 \%$ & $9.97 \%$ & $15.22 \%$ \\
\hline
\end{tabular}

From Table 2 above, $1.20 \%$ respondents agree that every English language teacher is capable of teaching literature successfully, $2.52 \%$ strongly agree, $9.9 \%$ disagree and $15.22 \%$ strongly disagree.

A high percentage is recorded for respondents who strongly disagree while low percentage is recorded for those who agree. This therefore indicates that English language teachers are not capable of handling literature successfully, hence the need for dichotomy of specialization. 
Anana: The Dichotomy of Specialization: Is a Literature Teacher Necessarily a Language Teacher?

\section{Table 3}

\begin{tabular}{|l|l|l|l|l|l|}
\hline Questionnaire Item & A & SA & D & SD \\
\hline 2. & $\begin{array}{l}\text { Literature should be taught } \\
\text { by literature experts } \\
\text { (qualified teachers) and } \\
\text { English by English } \\
\text { teachers. }\end{array}$ & & & & \\
\hline
\end{tabular}

Table 3 above shows that $8.40 \%$ respondents agree that literature should be taught by literature experts and English by English experts. $13.27 \%$ strongly agree, (They accept a dichotomy of specialization), 2.00 disagree and $1.60 \%$ strongly disagree. Both those who disagree and strongly disagree recorded low percentage especially those who strongly disagree, hence the need for dichotomy of specialization.

\section{Table 4}

\begin{tabular}{|l|l|l|l|l|l|}
\hline & Questionnaire Item & A & SA & D & SD \\
\hline 3 & $\begin{array}{l}\text { It is possible for a teacher } \\
\text { to place equal emphasis } \\
\text { on both language and } \\
\text { literature in classrooms. }\end{array}$ & $2.52 \%$ & $1.51 \%$ & $10.64 \%$ & $13.94 \%$ \\
\hline
\end{tabular}

Table 4 above indicates that $2.52 \%$ respondents agree that it is possible for a teacher to place equal emphasis on the two subjects, $1.51 \%$ strongly agree, $10.64 \%$ disagree and $13.94 \%$ strongly disagree. The percentage of those who strongly disagree is high and this indicates that it is not possible for a teacher to place equal emphasis on both English language and literature. 


\section{Table 5}

\begin{tabular}{|l|l|l|l|l|l|}
\hline & Questionnaire Item & A & SA & D & SD \\
\hline 4 & $\begin{array}{l}\text { Student's career choices are } \\
\text { not affected if a teacher } \\
\text { teaches both literature and } \\
\text { English language. }\end{array}$ & $2.60 \%$ & $2.52 \%$ & $10.50 \%$ & $11.37 \%$ \\
\hline
\end{tabular}

Table 5 above shows that $3.60 \%$ respondents agree that students' career choices are not affected if a teacher that teaches English is the same that teaches literature. $2.52 \%$ strongly agree, $10.50 \%$ disagree and 11.37 strongly disagree. This means that students' career choices are affected once the teachers take both subjects.

\section{Table 6}

\begin{tabular}{|l|l|l|l|l|l|}
\hline & Questionnaire Item & A & SA & D & SD \\
\hline 5 & $\begin{array}{l}\text { There would be the birth } \\
\text { of specialization if the } \\
\text { subjects are handled by } \\
\text { one teacher }\end{array}$ & $9.60 \%$ & $1.51 \%$ & $10.64 \%$ & $13.94 \%$ \\
\hline
\end{tabular}

Table 6 shows that $9.60 \%$ agree that there would be the birth of specialization if the two subjects are handled by one teacher. $1.51 \%$ respondents strongly agree, $10.64 \%$ disagree and $13.94 \%$ strongly disagree. High percentages are recorded for those who disagree and strongly disagree; it therefore means that to attain specialization, the two subjects should be taught by different teachers who specialize on individual subjects. 
Anana: The Dichotomy of Specialization: Is a Literature Teacher Necessarily a Language Teacher?

\section{Table 7}

\begin{tabular}{|l|l|l|l|l|l|}
\hline & Questionnaire Item & A & SA & D & SD \\
\hline 6 & $\begin{array}{l}\text { Teachers' } \\
\text { specialization in } \\
\begin{array}{l}\text { English and Literature } \\
\text { does not affect } \\
\text { student's } \\
\text { performance. }\end{array}\end{array}$ & $2.28 \%$ & $10.50 \%$ & $11.53 \%$ \\
\hline
\end{tabular}

Table 7 above indicates that $3.00 \%$ respondents agree that specialization in English and literature does not affect students' performance. $2.28 \%$ strongly agree, $10.50 \%$ disagree and $11.53 \%$ strongly disagree. This shows that teachers' specialization either in English or literature can affect student's performance.

\section{Table 8}

\begin{tabular}{|l|l|l|l|l|l|}
\hline & Questionnaire Item & A & SA & D & SD \\
\hline 7 & $\begin{array}{l}\text { Students would lag } \\
\text { behind in areas where } \\
\text { teachers are not } \\
\text { proficient in teaching. }\end{array}$ & $7.80 \%$ & $9.10 \%$ & $5.31 \%$ & $3.68 \%$ \\
\hline
\end{tabular}

Table 8 shows that $7.80 \%$ respondents agree that students would lag behind in areas where teachers are not proficient. 9.10\% strongly agree, $5.31 \%$ disagree and 3.68 strongly disagree. Here, it is obvious that students would lag behind if teachers are not proficient in teaching. 


\section{Table 9}

\begin{tabular}{|c|c|c|c|c|c|}
\hline & Questionnaire Item & $\mathrm{A}$ & $\mathrm{SA}$ & $\mathrm{D}$ & SD \\
\hline 8 & $\begin{array}{lr}\text { Stress } & \text { patterns } \\
\text { cannot } & \text { be } \\
\text { effectively } & \text { taught } \\
\text { by many literature } \\
\text { teachers }\end{array}$ & $11.80 \%$ & $8.85 \%$ & $2.39 \%$ & $2.27 \%$ \\
\hline
\end{tabular}

Table 9 shows that $11.80 \%$ respondents agree that stress patterns cannot be effectively taught by many literature teachers. $8.85 \%$ strongly agree, $2.39 \%$ disagree and $2.27 \%$ strongly disagree. This therefore indicates that stress patterns cannot be effectively taught by many literature teachers as the highest percentage indicates.

\section{Table 10}

\begin{tabular}{|l|l|l|l|l|l|}
\hline & Questionnaire Item & A & SA & D & SD \\
\hline 9 & $\begin{array}{l}\text { Phonological analysis } \\
\text { suffers when Literature } \\
\text { teachers handle English } \\
\text { language }\end{array}$ & $\% .68$ & $7.20 \%$ & $3.98 \%$ & $3.84 \%$ \\
\hline
\end{tabular}

Table 10 shows that $10.68 \%$ respondents agree that phonological analysis suffers when literature teachers handle English language. 7.20\% strongly agree, $3.98 \%$ disagree and $3.84 \%$ strongly disagree. The highest percentage is $10.68 \%$ and this shows that phonological analysis suffers when literature teachers handle English. 
Anana: The Dichotomy of Specialization: Is a Literature Teacher Necessarily a Language Teacher?

\section{Table 11}

\begin{tabular}{|l|l|l|l|l|l|}
\hline 10 & Questionnaire Item & A & SA & D & SD \\
\hline $\begin{array}{l}\text { Literary criticisms } \\
\text { cannot be effectively } \\
\text { taught by English } \\
\text { language teacher. }\end{array}$ & $8.40 \%$ & $7.60 \%$ & $5.31 \%$ & $4.80 \%$ \\
\hline
\end{tabular}

Table 11 above shows that $8.40 \%$ respondents agree that literary criticisms cannot be effectively taught by English language teachers, $7.60 \%$ strongly agree, $5.32 \%$ disagree and $4.80 \%$ strongly disagree. The highest percentage is of those who agree that literary criticism can be taught effectively by English teachers.

\section{Table 12}

\begin{tabular}{|l|l|l|l|l|l|}
\hline & Questionnaire Item & A & SA & D & SD \\
\hline 11 & $\begin{array}{l}\text { Oral Literature } \\
\text { cannot be effectively } \\
\text { handled by English } \\
\text { teachers. }\end{array}$ & . & $5.70 \%$ & $9.30 \%$ & $7.21 \%$ \\
\hline
\end{tabular}

Table 12 indicates that $4.80 \%$ agree that oral literature cannot be effectively taught by English teachers, 5.70\% strongly agree, $9.30 \%$ disagree and $7.28 \%$ strongly disagree. This further means that English teachers can effectively handle oral literature because the highest percentage of $9.30 \%$ indicates respondents who disagree with the statement. 


\section{Table 13}

\begin{tabular}{|l|l|l|l|l|l|}
\hline & Questionnaire Item & A & SA & D & SD \\
\hline 12 & $\begin{array}{l}\text { Non-African } \\
\text { Literature cannot be } \\
\text { competently taught } \\
\text { by English teachers. }\end{array}$ & $6.36 \%$ & $6.83 \%$ & $8.24 \%$ & $4.96 \%$ \\
\hline
\end{tabular}

In table 13 above, $6.36 \%$ respondents agree that Non-African literature cannot be competently taught by English teachers, $6.83 \%$ strongly agree, $8.24 \%$ disagree and $4.96 \%$ strongly disagree. This therefore means that English language teachers can competently teach Non-African literature as the highest percentage of $8.24 \%$ indicates.

\section{Table 14}

\begin{tabular}{|l|l|l|l|l|l|}
\hline 13 & Questionnaire Item & A & SA & D & SD \\
\hline $\begin{array}{l}\text { Literature teachers } \\
\text { can teach oral } \\
\text { English effectively. }\end{array}$ & $6.00 \%$ & $6.19 \%$ & $8.37 \%$ & $6.08 \%$ \\
\hline
\end{tabular}

Table 14 above indicates that $6.00 \%$ respondentsagree that literature teachers can teach oral English effectively. 6.19\% strongly agree, $8.37 \%$ disagree and $6.08 \%$ strongly disagree. This shows that literature teachers cannot teach oral English as the highest percentage of 8.37 indicates. 
Anana: The Dichotomy of Specialization: Is a Literature Teacher Necessarily a Language Teacher?

\section{Table 15}

\begin{tabular}{|c|c|c|c|c|c|}
\hline & Questionnaire Item & $\mathrm{A}$ & $\mathrm{SA}$ & $\mathrm{D}$ & SD \\
\hline 14 & Students taught by & $8.40 \%$ & $7.59 \%$ & $5.31 \%$ & $4.80 \%$ \\
\hline & $\begin{array}{l}\text { English language } \\
\text { experts may not be } \\
\text { proficient in poetic } \\
\text { devices. }\end{array}$ & & & & \\
\hline
\end{tabular}

Table 15 shows that $8.40 \%$ respondents agree that students taught by English language may not be proficient in poetic devices; $7.59 \%$ strongly agree, $5.31 \%$ disagree and $4.40 \%$ disagree. This indicates that English language experts may not be proficient in poetic devices as the highest percentage of $8.40 \%$ shows.

\section{Table 16}

\begin{tabular}{|l|l|l|l|l|l|}
\hline & Questionnaire Item & A & SA & D & SD \\
\hline 15 & $\begin{array}{l}\text { Literature teachers may } \\
\text { not be able to teach } \\
\text { Semantics effectively }\end{array}$ & $7.80 \%$ & $8.10 \%$ & $5.31 \%$ & $4.96 \%$ \\
\hline
\end{tabular}

Table 16 above indicates that $7.80 \%$ respondents agree that literature teachers may not be able to teach semantics effectively. $8.10 \%$ strongly agree, $5.31 \%$ disagree and $4.96 \%$ strongly disagree. The highest percentage is $8.10 \%$ and this shows that literature teachers may not be able to handle semantics effectively.

\section{Findings}

From the analysis of the data above, we observed that out of the 15 items analyzedabove, only three items in Tables 11, 12 and 13 agree that there is no need for a dichotomy of specialization. In Table 11, a high percentage of $8.80 \%$ respondents agree that 
English teachers can teach literary criticism. In Table 12, a high percentage of $9.39 \%$ respondents agrees that English teachers can handle oral literature effectively. Also, in Table 13, a high percentage of $8.24 \%$ agrees that English language teachers can handle Non-African literature.

The remaining twelve items in Tables 1 to 10,14 and 15 indicate the need for dichotomy of specialization. We therefore recommend that there should be a dichotomy of specialization in English Language and Literature. In other words, English Language teachers should teacher only English language while Literature teachers should also teach literature only, so that the students can benefit maximally in and outside the classrooms.

\section{Conclusion and Recommendations}

Many teachers of English language in both primary and secondary schools in Nigeria are the same teachers that teach literature. This combination has negatively affected both the teachers and the students. Teaching becomes tasking and students do not benefit maximally from it. Lack of specialisation is detrimental even to the future of education because the business of education is to be conducted in English. This paper has discovered that the teachers of English language cannot competently teach literature. It therefore maintains that there should be a dichotomy of specialisation in both subjects so that teaching and learning can be productive, healthy and result oriented for both the teachers and their students. The paper thereby recommends the following:

i. Although Literature and English language are interrelated, they are separate subjects; therefore,English language should be taught by English experts and literature by literature experts so as to obtain effective and result-oriented teaching. 
ii. Hunter (1997 cited in Ayodeji) states that teaching is one of the most stressful occupations; therefore, teachers' unnecessary workloads should be reduced so that they can live long and teach effectively. This can only be done if they concentrate on the subjects of their specialization.

iii. The government and private school administrators should pay both English language and literature teachers very well so that there would be no temptation for some of these teachers to merge the two subjects.

iv. The society should have regard for teachers so as to encourage them to teach.

These recommendations are given to ensure that the teaching and learning of English language and literature in primary and secondary schools in Nigeria are effectively done.

\section{Anana Mariam}

Department of Languages

Mountain Top University

Lagos-Ibadan Expressway

Ogun State

meanana@mtu.edu.ng 


\section{References}

Ayodeji, P. (1998). Teaching for Innovation. Ibadan: Lade-Oye Publishers

Anana, M. (2013). Communication in English and Literary Appreciation. Lagos: EmmanLaf (Nig) Enterprises

Austin, J. (1962). How to do things with words. Cambridge: Harvard University Press

Finnegan, R. (1984). Oral Literature in Africa. Nairobi: Oxford University Press

Musgrove, F. (1974). "Education of Teachers for a Changing Role", in J.D. Turner and J. Rushton (eds). The Teacher in a Changing Society. Manchester: Manchester University Press.

Mannheim, K and Steward, W.A.C. (1962). An Introduction to the Sociology of Education. London: Routledge and Kegan Paul.

McCrum, R. Macneil, .R and Cran, W. The Story of English.Penguinrandomhouse.com/books/86466/the_story_ of_english_by_robert_mccrum_robert_macneil_and_willia m_cram/. Accessed 13/8/2013

Peter, R. (1966). Education as Initiation. London: Routledge and Kegan Paul.

Poller, S. and Crystal D. Encyclopadia britinnica. from britannican.com/topic/English language. Accessed /3/2020

Osajie, E. (2004). Complete Guide to Literature in English for College. Benin: J \&S Communications

Roberts, E. and Jacobs, H. (2007). Literature: An Introduction to Reading and Writing. London: Pearson Prentice Hall. 


\section{APPENDIX}

Dear Sir/Ma,

Request to complete questionnaire on a topic, "The Dichotomy of Specialization: Is a Literature Teacher Necessarily a Language Teacher?"

Please find the attached questionnaire designed to solicit information from you for the above named research. Please supply and /or complete the questionnaire as required. Please be assured that the information supplied will be used purely for academic purpose and will also be treated with utmost confidentiality.

\section{QUESTIONNAIRE ON "THE DICHOTOMY OF SPECIALIZATION: IS A LITERATURE TEACHER NECESSARILY A LANGUAGE TEACHER?"}

SECTION A

BIO-DATA

Sex:

Age:

\section{SECTION B}

\section{GENERAL INFORMATION}

Please kindly tick your response(s) to each of the items below. They are rated as follows:

SA -Strongly Agree
A-Agree
D-disagree
SD -Strongly Disagree

Female

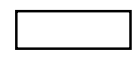




\begin{tabular}{|l|l|l|l|l|}
\hline ITEMS & A & SA & D & SD \\
\hline $\begin{array}{l}\text { Every English language teacher is } \\
\text { capable of teaching literature } \\
\text { successfully }\end{array}$ & & & & \\
\hline $\begin{array}{l}\text { Literature should be taught by } \\
\text { literature experts qualified teachers } \\
\text { and English by English teachers. }\end{array}$ & & & & \\
\hline $\begin{array}{l}\text { It is possible for a teacher to place } \\
\text { equal emphasis on both language } \\
\text { and literature in classrooms }\end{array}$ & & & & \\
\hline $\begin{array}{l}\text { Student's career choices are not } \\
\text { affected if a teacher teachers both lit } \\
\text { and English language }\end{array}$ & & & & \\
\hline $\begin{array}{l}\text { There would be dearth of } \\
\text { specialization if the subjects are } \\
\text { handled by one teacher }\end{array}$ & & & & \\
\hline $\begin{array}{l}\text { Specialization in English and } \\
\text { Literature does not affect student's } \\
\text { performance. }\end{array}$ & & & & \\
\hline $\begin{array}{l}\text { Students would lag behind in areas } \\
\text { where teachers are not proficient }\end{array}$ & & & & \\
\hline $\begin{array}{l}\text { Stress patterns cannot be effectively } \\
\text { taught by a literature teacher }\end{array}$ & & & & \\
\hline $\begin{array}{l}\text { Phonological analysis suffers when } \\
\text { Literature teachers handle English } \\
\text { language }\end{array}$ & & & & \\
\hline $\begin{array}{l}\text { Literary criticisms cannot be } \\
\text { effectively taught by English } \\
\text { language teacher }\end{array}$ & & & & \\
\hline Oral Literature cannot be effectively & & & & \\
\hline
\end{tabular}


Anana: The Dichotomy of Specialization: Is a Literature Teacher Necessarily a Language Teacher?

\begin{tabular}{|l|l|l|l|l|}
\hline handled by English teachers & & & & \\
\hline $\begin{array}{l}\text { Non-African Literature cannot be } \\
\text { competently taught by English } \\
\text { teachers }\end{array}$ & & & & \\
\hline $\begin{array}{l}\text { Literature teachers can teach oral } \\
\text { English effectively. }\end{array}$ & & & & \\
\hline $\begin{array}{l}\text { Students taught by English language } \\
\text { experts may not be proficient in } \\
\text { poetic devices. }\end{array}$ & & & & \\
\hline $\begin{array}{l}\text { Literature teachers may not be able } \\
\text { to teach Semantics effectively }\end{array}$ & & & & \\
\hline
\end{tabular}

